[Regular Paper]

\title{
Competitive Reaction in Hydrodenitrogenation and Hydrodeoxygenation of Coal-derived Naphtha
}

\author{
Motoi MACHIDA ${ }^{\dagger 1) *}$, Yasuo SAKAO ${ }^{\dagger 2)}$, and Shigeyoshi $\mathrm{ONO}^{\dagger 3)}$ \\ ${ }^{\dagger 1}$ Central Research Lab., Idemitsu Kosan Co., Ltd., Kamiizumi, Sodegaura, Chiba 299-02 \\ +2) Chiba Refinery, Idemitsu Kosan Co., Ltd., Anesaki-Kaigan, Ichihara, Chiba 299-01 \\ †3) Energy Development Dept., Idemitsu Kosan Co., Ltd., 3-1-1 \\ Marunouchi, Chiyoda-ku, Tokyo 100
}

(Received March 2, 1993)

\begin{abstract}
Hydrodenitrogenation (HDN) and hydrodeoxygenation (HDO) of coal-derived naphtha and its model compounds were examined by using a catalyst nickel-molybdenum supported on alumina. There are three types of nitrogen compounds in coal-derived naphtha. They are pyridine, pyrrole, and aniline. Aniline type nitrogen compounds in the coal-derived naphtha are more resistant to HDN than pyridine type compounds, though aniline is more reactive than pyridine when the reaction is carried out individually or singly. It is concluded that inconsistent results observed can be interpreted in terms of the competitive adsorption of the reactants onto the catalyst surface, as well as in terms of the reactivities of the reactants. Nitrogen compounds also restricted the HDO of phenolic compounds.
\end{abstract}

\section{Introduction}

The naphtha fraction derived form coal is expected to be one of the most suitable blending stocks for motor gasoline because of its high contents of cyclic hydrocarbons. Hydrogenated coal naphtha has been found to be preferable for reforming to the corresponding petroleum fraction in our preliminary study. Since the contents of nitrogen and oxygen are high in the coal naphtha, the amounts of these elements must be reduced to acceptable levels to meet the specification of nitrogen content less than $1 \mathrm{Nppm}$ for the consecutive reforming step. While removing sulfur is the main objective in hydrotreating of petroleum naphtha, removing nitrogen and oxygen is essential for coal naphtha. It is widely recognized that the removal of nitrogen- and oxygen-containing compounds requires severer conditions than the removal of sulfur-containing compounds ${ }^{1) \sim 9)}$. The properties of coal naphtha will affect HDN and HDO performances. However, most of the studies on HDN and HDO have been developed with a single model compound system; and neither practical feed stocks nor mixtures of model compounds have been satisfactorily examined compared with single model compounds $^{3) \sim 9)}$. In this work three kinds of coal naphtha have been investigated; naphthas derived

* To whom correspondence should be addressed. from Wandoan and Illinois \#6 sub-bituminous coal with $1 \mathrm{t} / \mathrm{d}$ Process Support Unit (PSU) of NEDOL process in Japan and the naphtha derived from Yallourn brown coal with $50 \mathrm{t} / \mathrm{d}$ Brown Coal Liquefaction (BCL) process in Australia. The aim of this study is to clarify the HDN and HDO performances of practical feed stocks and to compare the model reactions of several representative nitrogen- and oxygen-containing compounds which are found in coal-derived naphthas.

\section{Experimental}

\section{1. Coal-derived Naphtha and Model Com- pounds}

Three types of coal-derived naphthas, Wandoan, Illinois \#6 and Yallourn coal-derived naphthas were used for reaction. Chemicals for HDN and HDO model reactions were obtained from commercial sources, their purity was more than $99 \%$, and they were used without further purification. All the nitrogen- and/or oxygen-containing model compounds were added to toluene. Carbon disulfide was also added to the toluene solvent to maintain catalyst activity.

\section{2. Reaction Apparatus and Procedure}

Experiments were conducted at $300^{\circ} \mathrm{C}$ under the pressure of $3.0 \mathrm{MPa}$, the hydrogen to oil ratio of $700 \mathrm{Nm}^{3} / \mathrm{k} l$ in a fixed-bed, down flow conventional plug flow reactor as shown schematically in Fig. 


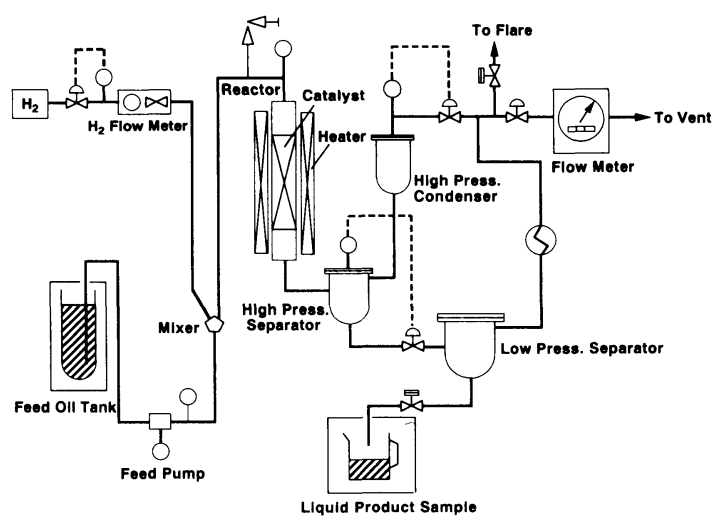

Fig. I Schematic Diagram of the Reaction System

1. The liquid hourly space velocity (LHSV) was varied to observe any changes in HDN and HDO performances. The catalyst employed was S424, $3.2 \%$ nickel, $13.2 \%$ molybdenum supported on alumina. This type of catalyst has proved to be more favorable than cobalt-molybdenum supported on alumina for HDN because of the high hydrogenation activity of nickel molybdenum catalyst $^{10), 11)}$. Prior to use the catalyst was presulfided with straight run petroleum gas oil (LGO), $1.6 \%$ sulfur content, and under $5.0 \mathrm{MPa}$ at $350^{\circ} \mathrm{C}$ for $14 \mathrm{~h}$. Then the coal derived naphtha or a model compound was fed for $70 \mathrm{~h}$ to stabilize catalyst activity. The feed was mixed with hydrogen at the inlet of the reactor and heated up to the reaction temperature prior to contacting with the catalyst. For each run, the standard conditions; $300^{\circ} \mathrm{C}, 3.0 \mathrm{MPa}$, hydrogen to oil ratio of
$700 \mathrm{~N} \mathrm{~m}^{3} / \mathrm{k} l$, and LHSV of 2.0 , were used before and after the run to guarantee that the catalyst had not deactivated during the run.

\section{3. Analysis}

Gaseous products were measured by on-line gas flow meter and analyzed by on-line gas chromatography. Liquid products were measured using a load cell in order to calculate material balance, product yields and hydrogen consumption. The total nitrogen content in the liquid products was determined using a chemiluminescence analyzer (Mitsubishi Kasei, TN05). The amount of total oxygen was estimated by IR detection after converting the oxygenates to carbon monoxide in a combustion tube (Heraeus, CHN-O Rapid) under oxygen-free atmosphere. For identification and quantification of each molecule an external standard method, for carbon and oxygen a gas chromatography (HP5890II) equipped with an atomic emission detector (HP5921A), and for nitrogen a nitrogen-phosphorous detector were used, respectively.

\section{Results}

\section{1. HDN and HDO of Coal-derived Naphtha}

3. 1. 1. Properties of Coal-derived Naphtha

The properties of coal naphtha derived from NEDOL process (in Japan) and BCL process (in Australia) are tabulated in Table 1. Concentrations of the representative nitrogen- and oxygencontaining compounds are tabulated in Table 2. The nitrogen-containing compounds primarily consists of three types, namely, pyridine/

Table 1 Properties of Coal-derived Naphtha

\begin{tabular}{|c|c|c|c|c|c|}
\hline \multicolumn{2}{|c|}{ Liquefaction process } & $\mathrm{BCL}$ & \multicolumn{3}{|c|}{ PSU } \\
\hline \multicolumn{2}{|c|}{ Coal } & Yallourn & Illinois $\# 6$ & Illinois \#6 & Wandoan \\
\hline \multicolumn{2}{|c|}{ Fraction } & IBP- $180^{\circ} \mathrm{C}$ & IBP $-180^{\circ} \mathrm{C}$ & IBP $-200^{\circ} \mathrm{C}$ & IBP $-200^{\circ} \mathrm{C}$ \\
\hline \multicolumn{2}{|l|}{ Specific gravity } & \multicolumn{3}{|c|}{ Analysis } & 0.8005 \\
\hline Oxygen & {$[\mathrm{wt} \%]$} & 3.2 & 1.2 & 2.1 & 3.0 \\
\hline Nitrogen & [wt $\%]$ & 1,400 & 1,290 & 2,900 & 1,810 \\
\hline Sulfur & [wtppm] & 1,600 & 1,810 & 1,950 & 1,600 \\
\hline \multicolumn{6}{|c|}{ [vol\%] } \\
\hline \multicolumn{2}{|c|}{ Paraffin \& Naphthene } & 64.2 & 78.4 & 73.7 & 81.3 \\
\hline \multirow{2}{*}{\multicolumn{2}{|c|}{$\begin{array}{l}\text { Olefin } \\
\text { Aromatics }\end{array}$}} & 25.1 & 9.7 & 5.2 & 9.4 \\
\hline & & 10.7 & 11.9 & 21.1 & 9.3 \\
\hline \multicolumn{6}{|c|}{ Distillation $\quad\left[{ }^{\circ} \mathrm{C}\right]$} \\
\hline & IBP & 35 & 15 & 15 & 12 \\
\hline & $5 \%$ & 61 & 41 & 63 & 35 \\
\hline & $10 \%$ & 69 & 68 & 83 & 53 \\
\hline & $20 \%$ & 87 & 84 & 99 & 81 \\
\hline & $30 \%$ & 98 & 92 & 117 & 97 \\
\hline & $40 \%$ & 108 & 102 & 134 & 117 \\
\hline & $50 \%$ & 124 & 117 & 151 & 136 \\
\hline & $60 \%$ & 135 & 132 & 164 & 160 \\
\hline & $70 \%$ & 148 & 144 & 171 & 172 \\
\hline & $80 \%$ & 166 & 160 & 180 & 184 \\
\hline & $90 \%$ & 173 & 170 & 189 & $\begin{array}{l}107 \\
193\end{array}$ \\
\hline & $95 \%$ & 181 & 173 & 195 & 200 \\
\hline & EP & 196 & 219 & 211 & 216 \\
\hline
\end{tabular}


Table 2 Nitrogen- and Oxygen-compounds in Coal-derived Naphtha

\begin{tabular}{|c|c|c|c|c|c|c|c|c|}
\hline \multicolumn{3}{|c|}{ Coal-derived naphtha } & \multicolumn{5}{|c|}{ Nitrogen compounds [N wtppm] } & \multirow{2}{*}{$\frac{\text { Oxygen compounds [O wt\%] }}{\text { Phenol type }}$} \\
\hline Process & Coal & Fraction & Pyridine & Piperidine & Pyrrole & Pyrrolidine & Aniline & \\
\hline BCL & Yallourn & IBP- $180^{\circ} \mathrm{C}$ & 37 & 1 & 7 & 0 & 0 & 1.13 \\
\hline PSU & Illinois $\# 6$ & IBP- $180^{\circ} \mathrm{C}$ & 11 & 0 & 50 & 0 & 33 & 1.16 \\
\hline PSU & Illinois \#6 & IBP $-200^{\circ} \mathrm{C}$ & 12 & 7 & 40 & 1 & 306 & 2.49 \\
\hline PSU & Wandoan & $\mathrm{IBP}-200^{\circ} \mathrm{C}$ & 12 & 4 & 3 & 2 & 60 & 2.52 \\
\hline
\end{tabular}

Table 3 Hydrodenitrogenation Conditions of Coal-derived Naphtha

\begin{tabular}{|c|c|c|c|c|}
\hline Liquefaction process & $\mathrm{BCL}$ & \multicolumn{3}{|c|}{ PSU } \\
\hline Coal & Yallourn & Illinois \#6 & Illinois \#6 & Wandoan \\
\hline Fraction & $\mathrm{IBP}-180^{\circ} \mathrm{C}$ & IBP $-180^{\circ} \mathrm{C}$ & $\mathrm{IBP}-200^{\circ} \mathrm{C}$ & IBP $-200^{\circ} \mathrm{C}$ \\
\hline LHSV $\left[\mathrm{h}^{-1}\right]$ & 1.1 & 0.9 & 0.5 & 0.7 \\
\hline
\end{tabular}

Reaction conditions: $320^{\circ} \mathrm{C}, 30 \mathrm{~kg} / \mathrm{cm}^{2}, 700 \mathrm{Nm}^{3} / \mathrm{k} l(\mathrm{~N}<\mathrm{l} \mathrm{ppm})$.

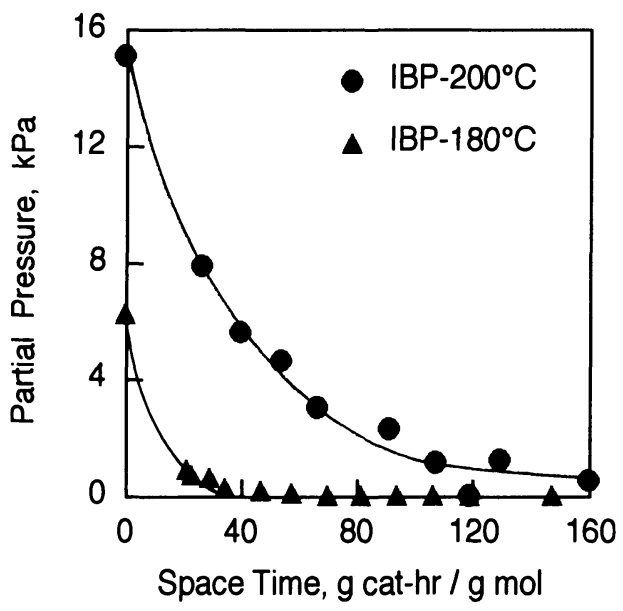

Fig. 2 Effect of Fraction Range on HDN (changes in nitrogen compounds partial pressure of IBP$200^{\circ} \mathrm{C}$ and IBP $-180^{\circ} \mathrm{C}$ fractions of Illinois \#6 coal-derived naphtha versus spacetime)

piperidine, pyrrole/pyrrolidine and aniline. The oxygen compounds mainly consists of phenolic compounds.

3. 1. 2. HDN and HDO of Coal-derived Naphtha

Table 3 tabulates the LHSV required for decreasing the nitrogen level less than $1 \mathrm{~N}$ ppm by keeping the other reaction conditions constant. Coal, liquefaction process, and fraction range affected the reaction conditions. Figure 2 shows the change in nitrogen contents of IBP $-180^{\circ} \mathrm{C}$ and $-200^{\circ} \mathrm{C}$ fractions of Illinois \#6 of NEDOL process as a function of reciprocal LHSV (IBP stands for initial boiling point). Apparently, IBP- $200^{\circ} \mathrm{C}$ fraction requires severer conditions to remove its nitrogen than IBP $-180^{\circ} \mathrm{C}$ fraction because not only of the higher content of nitrogen in IBP $-200^{\circ} \mathrm{C}$ fraction but also because of the higher content of aniline type nitrogen-containing compounds which are the most resistant nitrogen-containing compounds in coal naphtha as will be described below. Figure 3 shows the changes in pyridine/ piperidine, pyrrole and aniline contents of the IBP $-180^{\circ} \mathrm{C}$ fraction. Piperidine in Fig. 3 is the hydrogenated intermediate found in HDN of pyridine. In the coal-derived naphtha, aniline is more resistant than pyridine or pyrrole to HDN. Furthermore the HDN curve of aniline in Fig. 3 has a point of reflection. As HDN of pyridine or pyrrole proceeded, HDN of aniline is accelerated. A similar performance was also observed in HDN of the IBP $-200^{\circ} \mathrm{C}$ fraction. As shown in Table 2, the IBP $-200^{\circ} \mathrm{C}$ fraction of Illinois $\# 6$ contains aniline about an order of magnitude larger than in the IBP- $180^{\circ} \mathrm{C}$ fraction. And the content of all aniline-type compounds is proportional to the content of aniline. Consequently, the IBP $-200^{\circ} \mathrm{C}$ fraction contains not only more nitrogencontaining compounds, but more resistant compounds to $\mathrm{HDN}$ than the IBP $-180^{\circ} \mathrm{C}$ fraction.

Figure 4 shows the change as a function of reciprocal LHSV in the phenolic oxygen compounds, which are practically the entire oxygenates in coal naphtha derived from Illinois \#6. The rate of hydrodeoxygenation (HDO) is faster in the IBP $-180^{\circ} \mathrm{C}$ fraction than in the IBP $-200^{\circ} \mathrm{C}$ fraction. In $\mathrm{HDO}$ of phenolic compounds, the initial rate of $\mathrm{HDO}$ is increased with increasing initial content of phenolic compounds. The inconsistent results in this case is resulted from the inhibition effects of nitrogen compounds as will be described below.

\section{2. HDN and HDO of Model Compounds}

3. 2. 1. Properties of the Feeds of Model Reaction

Pyridine, pyrrole and aniline as typical nitrogen-containing compounds were added to the toluene solvent and made to react individually or singly (referred to as a single nitrogen-containing 


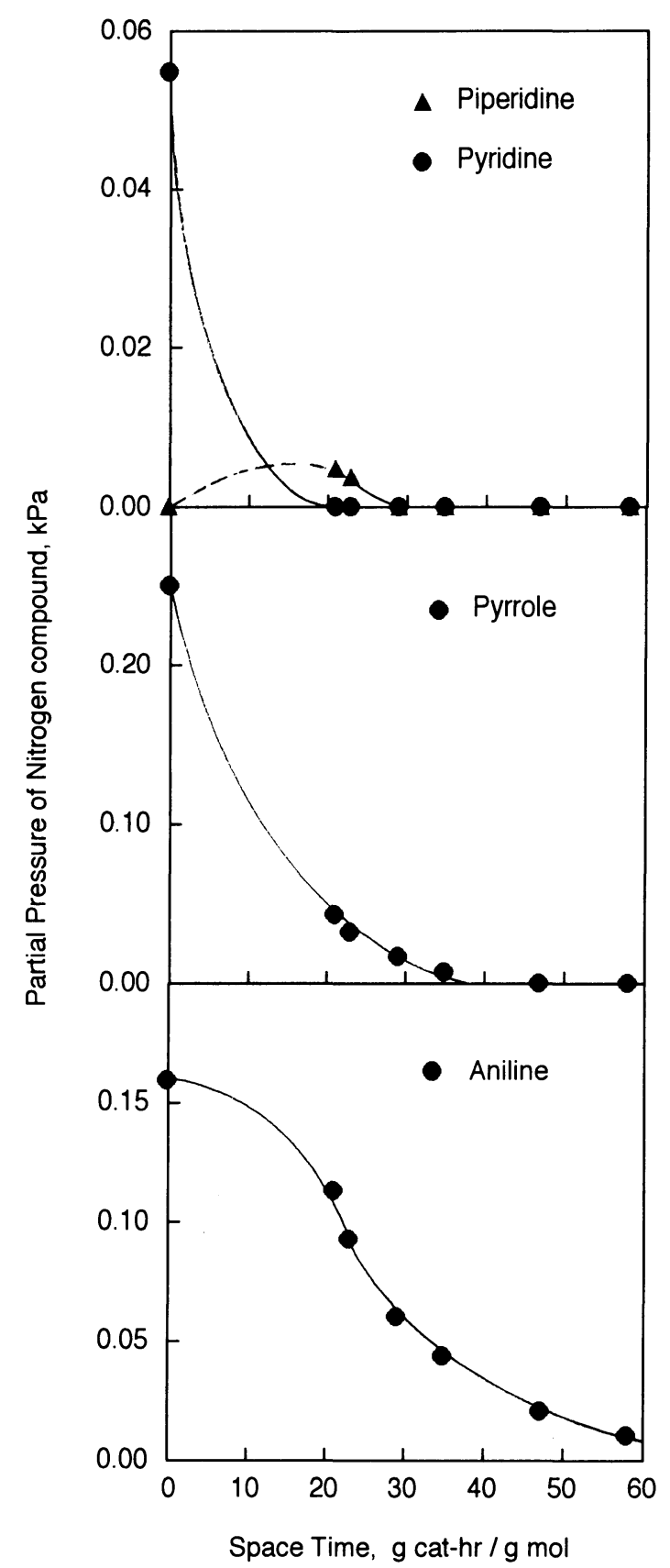

Fig. 3 Changes in Partial Pressure of Pyridine/ Piperidine, Pyrrole, and Aniline in IBP- $180^{\circ} \mathrm{C}$ Fraction of Illinois \#6 Coal-derived Naphtha versus Spacetime

system or reaction). In the other case, all the compounds were added together and made to react simultaneously (referred to as three nitrogencompound system). On the one hand, each nitrogen-containing model feed for single system was prepared to meet the requirement of $0.3 \mathrm{~N} \mathrm{wt} \%$ nitrogen content. On the other hand, the feed for three nitrogen-containing system, the total content was also $0.3 \mathrm{~N}$ wt $\%, 0.1 \mathrm{~N}$ wt\% each. Phenol as a

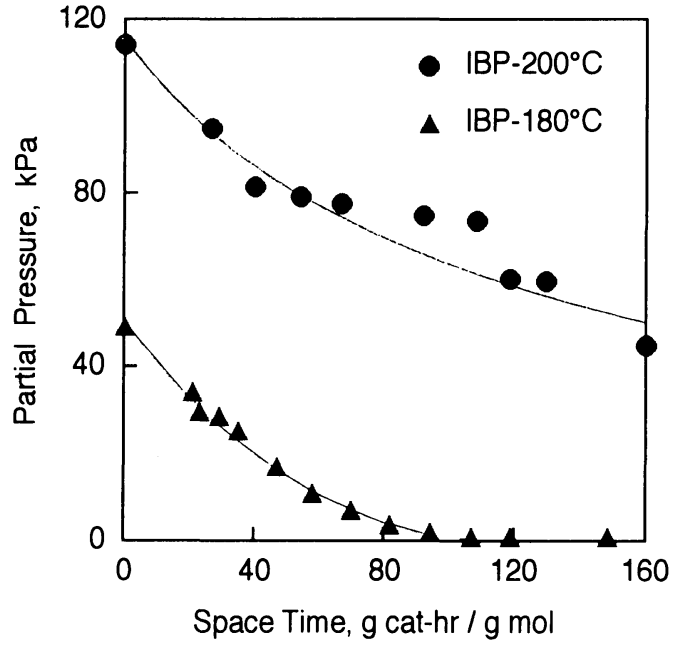

Fig. 4 Effect of Fraction Range on HDO (changes in partial pressure of phenolic oxygen compounds of IBP $-200^{\circ} \mathrm{C}$ and $\mathrm{IBP}-180^{\circ} \mathrm{C}$ fractions of Illinois \#6 coal-derived naphtha versus spacetime)

typical oxygen-containing compounds were blended with the solvent in the amount of $2.0 \mathrm{Owt} \%$. A model feed containing three nitrogen compounds, $0.1 \mathrm{~N} \mathrm{wt} \%$ each, and phenol, $2.0 \mathrm{O} \mathrm{wt} \%$, was also prepared to examine the interaction between nitrogen- and oxygencontaining compounds. All the model feeds contained $0.2 \mathrm{~S} w \mathrm{t} \%$ carbon disulfide to maintain the catalytic activity.

\section{2. 2. HDN of Model Nitrogen Compounds}

Figure $5(\mathbf{A})$ and $(\mathbf{B})$ show the results of HDN of representative nitrogen-containing compounds, which are contained in the coal-derived naphtha. In $(\mathbf{A})$ are shown the results of HDN reaction of nitrogen-containing compounds of pyridine, pyrrole and aniline carried out individually at the same initial nitrogen content and under the same reaction conditions. In contrast, in $(\mathbf{B})$ are the results of HDN reaction of a pyridine, pyrrole, and aniline mixture in which the reaction was performed simultaneously as coal-derived naphtha. In the case of the single reaction, the removal of pyridine (pyridine and piperidine) was the most resistant among the three nitrogen compounds as indicated in Fig. 5 (A). This is an inconsistent result with the result of $\mathrm{HDN}$ of coal-derived naphtha. However, the result of the simultaneous reaction of the three nitrogen compounds in the same phase shown in Fig. 5 (B) represents a similar performance as that of the coal-derived naphtha as shown in Fig. 3.

\section{2. 3. HDO of Model Oxygen Compounds}

Phenol is the most abundant oxygen-containing compound in coal-derived naphtha. Therefore 

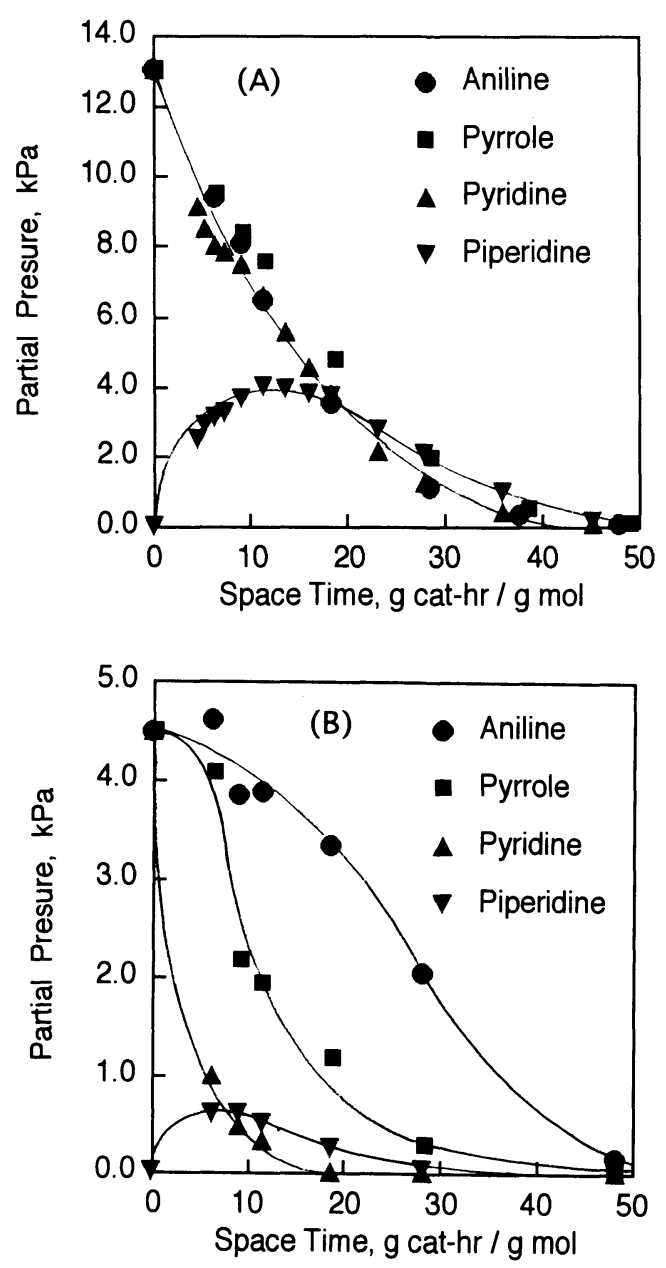

Fig. 5 Changes in Partial Pressure of Pyridine/ Piperidine, Pyrrole, and Aniline in Individual Reaction (A) and Simultaneous Reaction (B) versus Spacetime in Model Reaction

hydrodeoxygenation (HDO) of model reaction was examined by using phenol. The contents and compositions of nitrogen-containing compounds are the same as the model feed of simultaneous reaction of the three nitrogen compounds. Figure 6 represents the HDO performance of phenol for the cases of including and not including nitrogen-containing compounds. HDO of phenol is strongly inhibited by the nitrogencontaining compounds. This performance is similar to that of coal-derived naphtha.

\section{Discussion}

\section{1. HDN Performance of Coal-derived Naph- tha}

Typical nitrogen-containing compounds in coal-derived naphtha are pyridine, pyrrole, and aniline and their alkyl derivatives. Though aniline and pyrrole are more reactive than pyridine

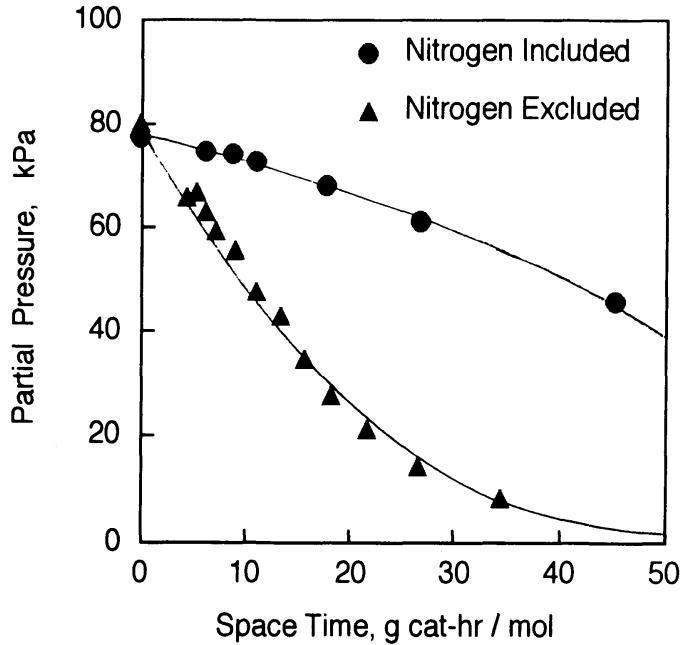

Fig. 6 Inhibition Effects of Nitrogen Compounds on HDO of Phenol (changes in phenol partial pressure in nitrogen compounds included and excluded case in model reaction)

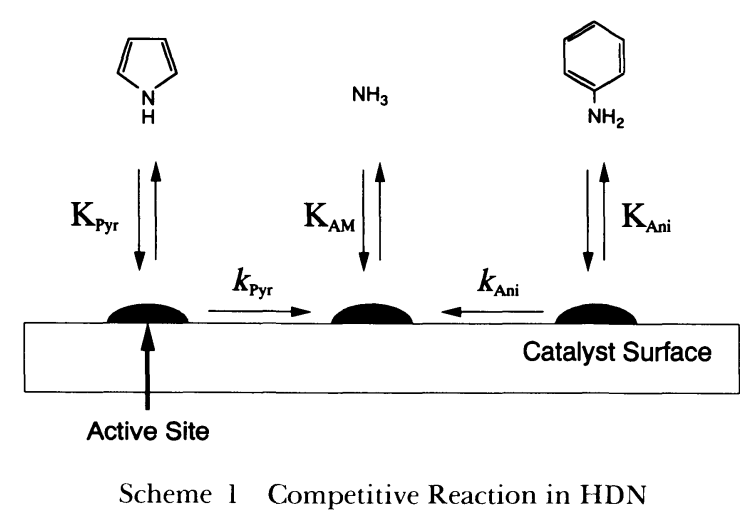

in the single reactions; aniline was the least reactive in simultaneous reactions such as HDN of coalderived naphtha and mixtures of nitrogen compounds. It is generally recognized that a Langmuir-Hinshellwood type kinetic expression is employed to represent the HDN reaction. For instance, as shown in Scheme 1, aniline is as reactive as pyrrole if the reaction is examined individually.

On the one hand, the rate of HDN was expressed as follows, assuming that hydrogen was adsorbed on different sites from the sites on which nitrogencontaining compounds was adsorbed.

$$
\begin{aligned}
-\frac{\mathrm{d} P_{\mathrm{pyr}}}{\mathrm{d} t} & =\frac{K_{\mathrm{pyr}} P_{\mathrm{pyr}}}{1+K_{\mathrm{pyr}} P_{\mathrm{pyr}}+K_{\mathrm{AM}} P_{\mathrm{AM}}} P_{\mathrm{H} 2} k_{\mathrm{pyr}} \\
-\frac{\mathrm{d} P_{\mathrm{ani}}}{\mathrm{d} t} & =\frac{K_{\mathrm{ani}} P_{\mathrm{ani}}}{1+K_{\mathrm{ani}} P_{\mathrm{ani}}+K_{\mathrm{AM}} P_{\mathrm{AM}}} P_{\mathrm{H} 2} k_{\mathrm{ani}}
\end{aligned}
$$

$P_{\text {pyr }}, P_{\text {ani }}, P_{\text {AM }}$, and $P_{\mathrm{H} 2}$ donate partial pressures of 
pyrrole, aniline, ammonia, and hydrogen, respectively. $K_{\text {pyr }}, K_{\text {ani }}$, and $K_{\text {AM }}$ are the corresponding adsorption equilibrium constants. $k_{\text {pry }}$ and $k_{\text {ani }}$ are HDN rate constants of pyrrole and aniline. On the other hand, the rate of HDN is expressed as follows when pyrrole and aniline are existing in the same phase in which aniline is more resistant to HDN than pyrrole.

$$
\begin{aligned}
-\frac{\mathrm{d} P_{\mathrm{pyr}}}{\mathrm{d} t} & =\frac{K_{\mathrm{pyr}} P_{\mathrm{pyr}}}{1+K_{\mathrm{pyr}} P_{\mathrm{pyr}}+K_{\mathrm{ani}} P_{\mathrm{ani}}+K_{\mathrm{AM}} P_{\mathrm{AM}}} P_{\mathrm{H}_{2}} k_{\mathrm{pyr}} \\
-\frac{\mathrm{d} P_{\mathrm{ani}}}{\mathrm{d} t} & =\frac{K_{\mathrm{ani}} P_{\mathrm{ani}}}{1+K_{\mathrm{pyr}} P_{\mathrm{pyr}}+K_{\mathrm{ani}} P_{\mathrm{ani}}+K_{\mathrm{AM}} P_{\mathrm{AM}}} P_{\mathrm{H}_{2}} k_{\mathrm{ani}}
\end{aligned}
$$

HDN of nitrogen-containing compounds can be interpreted in terms of the competitive adsorption of each nitrogen-containing compound onto the catalyst surface. Nagai et al. ${ }^{9}$ explained the reactivity of nitrogen compounds in terms of gasphase basicity (GB); the adsorption equilibrium constant is proportional to GB's. Aue et al. ${ }^{12)}$ measured the gas-phase basicities of several nitrogen compounds and obtained order of GB as piperidine $(221.5 \mathrm{kcal} / \mathrm{mol})>$ pyridine $(220.4)>$ aniline (207) $>$ pyrrole (205). Myton et al. ${ }^{13)}$ calculated GB's from the heats of formation of 127 compounds containing carbon, hydrogen, nitrogen and oxygen. They also resulted in the same order as Aue et al. had determined. Therefore the reactivity of each nitrogencontaining compound could be explained by its $\mathrm{GB}$; the greater is the GB value of a molecule, the stronger is its adsorption onto the catalyst surface. This is expressed by $K_{\text {ani }}>K_{\text {pyr. }}$ As a consequence, the order of rate would be $r_{\mathrm{ani}}>r_{\mathrm{pyr}}$ because HDN rate is almost the same when HDN reaction is performed individually. The terms of $r_{\mathrm{ani}}$ and $r_{\mathrm{pyr}}$ stand for HDN rate of aniline and pyridine, respectively. In contrast to the single reactions, pyrrole is more reactive than aniline in simultaneous reactions. The value of $K_{\mathrm{pyr}} k_{\mathrm{pyr}}$ will then be larger than that of $K_{\text {ani }} k_{\text {ani. }}$. The denominator of the equation for the reaction of pyrrole and aniline together is the same at any reaction time.

\section{2. HDO Performance of Coal-derived Naph- tha}

As shown in Fig. 6, hydrodeoxygenation (HDO) of phenol is strongly inhibited by coexisting nitrogen-containing compounds. Though phenol is an acidic compound and such nitrogencontaining compounds as pyridine, pyrrole, and aniline are basic compounds, these two types of compounds react competitively ${ }^{14)}$ Myton et al. calculated the phenol GB value to be $149.6 \mathrm{kcal} /$ mol, while GB's of pyridine, pyrrole, and aniline were in the range of $199.4-209.8 \mathrm{kcal} / \mathrm{mol}$; moreover, the adsorption equilibrium constant of phenol would be less than the constants of the nitrogen-containing compounds. Consequently, the HDO of phenol could also be explained by the Langmuir-Hinshellwood type competitive reaction.

\section{Conclusions}

Hydrodenitrogenation (HDN) and hydrodeoxygenation (HDO) of coal naphthas derived from NEDOL Process, Process Support Unit, in Japan, and those derived from BCL Process in Australia were examined in order to clarify the reactivities of nitrogen- and oxygen-containing compounds, and the results are compared with those of individual reactions. A Lungmuire-Hinshellwood type competitive reaction is suggested for the reaction of HDN and HDO of practical feed stocks. Though aniline is the most reactive and the pyridine the least reactive among three representative nitrogencontaining compounds, pyridine, pyrrole, and aniline in the individual reactions, pyridine is denitrogenated in preference to aniline in both the simultaneous reaction and the coal naphtha reaction. It is clear that the accessibility of nitrogen-containing molecules to the catalyst surface, as well as their reactivities, gives a pronounced influence on the HDN and HDO performances in the reaction of practical feed stocks. Compounds that have relatively weak accessibility to the catalyst surface are easily inhibited from reaching the catalyst surface by other compounds in the feed stock.

\section{Acknowledgments}

This work was performed in the framework of Japan New Sun Shine Project on coal liquefaction conducted by AIST (Agency of Industrial Science and Technology) and NEDO (New Energy and Industrial Technology Development Organization). The authors greatly appreciate the encouragement and suggestions of Dr. $T$. Yamaguchi, Faculty of Science, Hokkaido University.

\section{References}

1) Moreau, C., Aubert, C., Durand, R., Zmimita, N., Geneste, P., Catalysis Today, 4, 117 (1988)

2) Satterfield, C. N., Cocchetto, J. F., AIChE J., 21, 1107 (1975).

3) Rollmann, L. D., J. Catal., 46, 243 (1977).

4) Badilla-Ohlbaum, R., Chadwick, D., Fuel, 58, 834 (1979).

5) Badilla-Ohlbaum, R., Pratt, K. C., Fuel, 58, 309 (1979).

6) Chu, C.-I., Wang, I., Ind. Eng. Chem., Process Des. Dev., 21, 
338 (1982).

7) Katti, S. S., Westerman, D. B., Gates, B. C., Ind. Eng. Chem., Process Des. Dev., 23, 773 (1983).

8) Nagai, M., Masunaga, T., J. Catal., 101, 284 (1986).

9) Nagai, M., Masunaga, T., Fuel, 67, 771 (1988).

10) Ahuja, S. P., Derrien, M. L., Lepage, J. F., Ind. Eng. Chem.,
Prod. Res. Dev., 9, 272 (1970).

11) Aboul-Gheit, A. K., Appl. Catal., 16, 39 (1985).

12) Aue, D. H., Webb, H. M., Bowers, M. T., J. Am.Chem. Soc., 98, 318 (1976)

13) Myton, D. M., O'Brien, R., J. Anal. Chem., 63, 1201 (1991).

14) Odebunmi, E. O., Ollis, D. F., J. Catal., 80, 76 (1983).

要旨

石炭液化油ナフサ留分の水素化脱窒秦, 眖酸票における反応物の相互阻害

\author{
町田 基 $^{\dagger 1)}$, 坂尾泰男 ${ }^{\dagger 2)}$, 小野重好 ${ }^{\dagger 3)}$ \\ ${ }^{\dagger 1)}$ 出光興産(株)中央研究所, 299-02 千葉県袖ヶ浦市上泉 1280 \\ †2)出光興産(株)千葉製油所, 299-01 千葉県市原市姉崎海岸 2-1 \\ ${ }^{\dagger 3}$ 出光興産(株)新燃料部事業開発課, 100 東京都千代田区丸八内 3-1-1
}

$\mathrm{Ni}-\mathrm{Mo} / \mathrm{Al}_{2} \mathrm{O}_{3}$ 系触媒にて石炭液化油ナフサ留分とそのモデ ル物質の水素化脱窒素と水素化脱酸素を調べた。石炭液化油に ついては沸点範囲が変わったときに反応速度にどのように影響 を及ほすかを主に調べた。液化油中には含窒素化合物としてア ニリン, ピロールおよびピリジン系の化合物, 含酸素化合物と してフェノール系の化合物が含まれる。アニリン，ピロール， ピリジンの脱窒素を個別に調べるとアニリンの反応が最も速い
が，液化油のようにこれらの窒素化合物が共存している系で は, 逆にアニリンの脱窒素が最も遅くなる。さらに, 窒素化合 物とフェノール系の酸素化合物が共存した場合, 窒素化合物は 脱酸素反応を阻害する。これらの現象は窒素化合物同士，また は窒素化合物と酸素化合物の間での競争吸着メカニズムで説明 できる。

\title{
Keywords
}

Naphtha, Nitrogen compound, Oxygen compound, Hydrodenitrogenation, Hydrodeoxygenation 